\title{
Work Values, Organisational Commitment and Job Satisfaction in Relation to Employee Career Stages in Information Technology Organisations
}

\author{
Arti Arun Kumar
}

\begin{abstract}
The booming Information Technology sector in India has changed the employee-employer relationship. This article investigates the relationship between career stages and work values, organisational commitment and job satisfaction of employees to gain new insights. 190 employees at various career stages were administered three standardised reliable and valid questionnaires on work values, organisational commitment and job satisfaction. A significant difference in cognitive, affective, and instrumental values was seen across career stages. In addition, career stages were found to have no impact on organisational commitment and job satisfaction.
\end{abstract}

Keywords: Career Stages, Job Satisfaction, Organisational Commitment

\section{Introduction}

The Information Technology industry is one of the fastest growing sectors in India. The transformation has indeed been phenomenal with India emerging as the world leader in information technology and business outsourcing. However, with it, certain critical

\footnotetext{
* Institute of Management, CHRIST (Deemed to be University), India; arti.kumar@christuniversity.in
} 
challenges emerge such as employee engagement, growing alienation, lack of an empathic leadership and increasing stress levels.

This will have serious ramifications on the Information Technology industry as in the $\mathrm{BPO}$ workforce, 88 percent of the employees are under the age of 35 . It was found that one 3rd of the employees were below the age of 25 and it was employees in the age group of 26 to 35 that had the lion's share of the total workforce. They comprised of 55 per cent of the total. The next age group that is 35 to 45 years occupied approximately 10 per cent of the lot. Those above this age limit i.e. 45 plus had only a small share of just two per cent of the total (NASSCOM HR Survey Report, 2011). The attrition rate in Indian BPOs has increased to 55 per cent in the last four months. During December 2010-April 2011, the attrition rate in the business process outsourcing (BPOs) has increased to 55 per cent from about 40 per cent in the same period the previous year.

In this scenario, employee engagement would take a different meaning altogether. It is clear that it is the youngest in the workplace who are the most disengaged and the Indian workplace will have a large number of $45+$ year olds in the industry, working alongside with a number of young people. Each brings with themselves their unique experiences, value systems, attitudes such as organisational commitment, job satisfaction, perceptions of employability and perceptions of job insecurity (Rhodes, 1983; Slocum \& Cron, 1985; Smola \& Sutton 2002; Twenge \& Campbell, 2008), concerns and motivation.

The Information Technology sector is characterised by a new creed of workers called knowledge workers. Knowledge workers are defined as high-level employees who apply theoretical and analytical knowledge that is acquired through formal education in developing new products or services (Drucker, 1992). Such knowledge workers are among the fastest-growing segments of the workforce and are in one of the groups most likely to use teams (Beyerlein, Johnson \& Beyerlein, 1999).

Knowledge workers are connecting differently with their employers and the psychological contract between employer and employee has changed fundamentally in order to keep up with the 
constant state of change and technological advances that the industry faces on an ongoing basis. A loyalty clash exists, as knowledge workers generally identify with a high technology culture which is separate from the bureaucratic organisation employing them thus the work values, needs and expectations of these employees are going to vary from career stage to career stage. It becomes imperative for organisations to gain deeper insight into these aspects to enhance organisation commitment and job satisfaction.

Much of the interest in analysing job satisfaction and organisational commitment stems from a concern for the behavioural consequences that are hypothesised to result from job satisfaction and/or organisational commitment. Job satisfaction and/ organisational commitment have been shown or argued to be related to productivity, attendance at work, turnover, retirement, participation, and psychological withdrawal from work.

Each individual passes through a series of stages characterised by changing patterns of developmental tasks, career concerns, activities, values and needs that emerge as a person ages and passes through various age ranges (Hall, 1973; Levinson et al., 1978). Similarly, at each career stage, each employee shows certain work-related behaviour through which the individual seeks to define, clarify and fulfill their psychological make-up, needs and values. For the purpose of the present study, we shall focus on the Super Career Stage Model $(1957,1980)$ (Table 1).

Table 1: Super's Career Development Model (Source: Ornstein, Cron \& Slocum, 1989).

\begin{tabular}{|c|c|}
\hline Career Stages & Psychological tasks to be achieved \\
\hline Trial & $\begin{array}{l}\text { To identify interests, capabilities, fit between self and } \\
\text { work, and professional self-image }\end{array}$ \\
\hline Establishment & $\begin{array}{l}\text { To increase commitments to career, career } \\
\text { advancements and growth } \\
\text { To develop a stable work and personal life }\end{array}$ \\
\hline Maintenance & $\begin{array}{l}\text { To hold on to accomplishment earlier received } \\
\text { To maintain self -concept }\end{array}$ \\
\hline Decline & $\begin{array}{l}\text { To develop a new self -image that is independent of } \\
\text { career success }\end{array}$ \\
\hline
\end{tabular}


Values have been defined as "desirable trans-situational goals that vary in importance as guiding principles in people "s lives" (Rokeach, 1973). They serve as a guiding post in order to surpass the obstacles that people face in their everyday life. Work values can be defined as "an objective, either a psychological state, a relationship or material condition that one seeks to attain" (Rokeach, 1973).

Elizur (1984) introduced a trichotomous classification of values based on the modality of respective outcomes. Instrumental values refers to tangible outcomes or rewards of work such as high income, material possession, generous holidays, working conditions, a good pension plan and job security. Affective values are social values related to interpersonal relationships, feeling of being loved, a fair supervisor, acceptance, esteem and responsible job. The third type is called cognitive values is related to interest, achievement, independence and may be considered as psychological in nature rather than social or material values.

Organisational commitment refers to an individual's overall feelings about the organisation. It is the psychological bond that an employee has with an organisation and has been found to be related to behavioral investments in the organisation, likelihood to stay with the organisation, and goal and value congruence (Steers \& Porter, 1982).

Job Satisfaction can be defined as the degree of satisfaction with the intrinsic and extrinsic nature of the job (Warr et al., 1979).

\section{Literature review}

Since the review of literature focused mainly on generational differences and not on career stages, certain assumptions were made by the researcher (Table 2). 
Arti Arun Kumar Work Values, Organizational Commitment and Job Satisfaction

Table 2: A Comparison between Super's Career Stages and Generations

\begin{tabular}{llll}
\hline Generations & Years & Age (2014) & Stage \\
\hline Baby Boomers & $1946-1964$ & 50 & Decline \\
Gen X & $1965-1976$ & 37 & Maintenance \\
Gen Y & $1977-1991$ & 23 & Establishment \\
Gen Z & 1991 & 23 and below & Trial \\
\hline
\end{tabular}

Results suggested that the Boomer managers (Decline stage) base their belief systems more on humanistic/moralistic values, where pre-Boomer managers were more traditional and pragmatic (Parker \& Cusmir, 1991).

Research also indicates that leisure values (instrumental values) have increased over generations (Twenge et al., 2010). Leisure values could be indicated as freedom related values. Thus, we can logically ascertain that in terms of Super Theory of Career Development those who are at the trial stage would prefer leisure values less than those who are the maintenance or decline stage.

Super's career stage theory (Super et al., 1981) indicated that individuals in the Trial and Establishment career stages are less likely to value security in a job, compared to those in the Maintenance and Decline career stages. Therefore they may be less concerned with perceptions of job insecurity. Trial and Establishment stage individuals, whose career identity is based on their career, rather than on their position in an organisation are likely to have higher perceptions of employability and lower perceptions of job insecurity.

Research indicates that work values also change as age increases. (Hansen \& Leuty, 2012; Smola \& Sutton, 2002). Significant generational differences were found for individual work values involving status and freedom but not for extrinsic, intrinsic, social and altruism related values Younger generations placed more importance on status than the older group. The career stage of the older group may provide status so they no longer feel the need to earn 
Social values (e.g., making friends) and intrinsic values (e.g., an interesting, results-oriented job) were rated lower by GenMe than by Boomers. Similar research also indicates that Gen $X$ (Maintenance Stage) place more importance on extrinsic values such as "Working Conditions, Security, Co-workers and Compensation" (Hansen \& Leuty, 2012).

Generation $Y$ who is highly technological savvy (Lyons, 2004) are known to value work/life balance, lifestyles, career development and overseas travel more than other generations (Zemke et al., 2000). This generation is said to value intrinsic aspects of work such as mentoring and training in order to remain marketable (Loughlin \& Barling, 2001; Lyons, 2004). However, some research indicates Generation Y may not favour altruistic values or intrinsic values any more than previous generations (Twenge et al., 2010). While the younger groups may feel that status is a priority as it provides visibility which aids progressions and marketability and freedomrelated values (Riordan et al., 2003).

Research on career stages and organisational commitment indicate that older employees view their past years of service to the organisation as an investment, and will have the psychological barrier that it would be more difficult for them to shift from one job to another. Long-service employees also develop affective attachment to their organisation or work from a transformational perspective. Therefore they tend to be more committed to the organisation Younger workers had a transactional focus (Ornstien et al., 1989; Waint, 1999).

It has been seen that organisational commitment does not increase with career stage (Rhodes, 1983). This could be due to the fact that the sample commitment to the profession rather than employing organisation. Individuals in the maintenance stage would have made a niche for themselves and more likely to progress in familiar ways. However, motivation for advancement and promotion decreased in the maintenance stage and is likely to relocate or leave their present employee. It has been seen that intrinsic work values relate more closely to organisational commitment than extrinsic work values (Putti et al., 1989) 
Results of the study revealed significant differences in organisational commitment across career stages of employees when career stages were categorised on the basis of chronological age but no significant difference in any dimension of organisational commitment has been found between employees in early-career stage (up to 2 years of experience), and employees in the midcareer stage (3-10 years of experience).

Generation $X$ members may have more commitment to their own careers than to their organisations (Lyons, 2004; Miller \& Yu, 2003)

Baby Boomers (Decline Stage ) have been found to rate the chance to learn new skills, personal improvement and creativity at work as important (Jurkiewicz, 2000; Lyons, 2004). A strong focus on hard work and achievement may mean that this group values status and extrinsic rewards as recognition for loyalty and commitment (Collins, 1998; Twenge et al., 2010) and may have difficulty balancing work and family (Lancaster \& Stillman, 2002; Smola \& Sutton, 2002; Zemke et al., 2000). Good supervisor relations and positive interactions with co-workers have also been found to be important (Karp et al., 2001).

There is a dearth of literature which connects the variables work values, organisational commitment and job satisfaction. Research indicated that there is no relationship between teacher satisfaction and career commitment (Bilz, 2008).

Research clearly indicates that there is a definite need to understand the relationship between career stages, work values, organisational commitment and job satisfaction. Also on the basis of the following hypothesis were generated:

H1 : Career stages influences work values of IT employees

H2 : Career stages influences job satisfaction of IT employees

H3: Career stages does not influence organisational commitment of IT employees

H4: There will be a difference in work values, organisational commitment and job satisfaction across demographics (gender, marital status, level of education) 


\section{Methods}

A total of nearly 2000 IT companies exist in the city of Bangalore (NASSCOM, 2017) A researcher approached 25 companies and administered the questionnaire to nearly 500 employees, 190 employees from organisations based in Bangalore answered to the questionnaire. Data were collected by means of a questionnaire given online and also filled personally by respondents which took approximately 20 minutes to complete. Primary data was collected and judgemental sampling technique was used.

\subsection{Measures}

Work values: Work Values Scales developed by Elizur (1984) was used to measure work values which consisted of three dimensions and 24 values. The three dimensions are cognitive values (14 values), instrumental values ( five values) and affective values ( five values) For )each value respondents were asked to rate "To what extent is each item a top priority for you in your work?" on a five point Likert scale. The Cronbach alpha was .977 showing good reliability

Job Satisfaction: The 15-item "job satisfaction scale" developed by Warr et al., (1979 was used to measure job satisfaction. Responses were on a five-point Likert scale from "1" indicating Very Dissatisfied to "5" indicating Very Satisfied. The Cronbach alpha was .921 showing good reliability.

Organisational commitment: The fifteen item "Organisational Commitment Questionnaire" (OCQ) was developed by Mowday, Steers and Porter (1979). Responses ranged from "Strongly disagree" to "Strongly agree". The Cronbach alpha was .721 showing good reliability.

Demographics: Additional items asked for participants' gender, age (representing career stages), education level, tenure in organisation (Table 3). 
Arti Arun Kumar Work Values, Organizational Commitment and Job Satisfaction

Table 3: Sample Description

\begin{tabular}{|c|c|c|c|c|c|c|c|c|}
\hline & $\begin{array}{c}\text { Trail } \\
\text { Stage } \\
(\mathrm{N}=60)\end{array}$ & $\%$ & $\begin{array}{c}\text { Establish- } \\
\text { ment } \\
\text { Stage } \\
(\mathrm{N}=50)\end{array}$ & $\%$ & $\begin{array}{c}\text { Main- } \\
\text { tenance } \\
\text { Stage } \\
(\mathrm{N}=40)\end{array}$ & $\%$ & $\begin{array}{c}\text { Decline } \\
\text { Stage } \\
(40)\end{array}$ & $\%$ \\
\hline \multicolumn{9}{|l|}{ Gender } \\
\hline Male) & 32 & 52.5 & 32 & 64 & 35 & 87.5 & 20 & 50 \\
\hline Female & 28 & 45.9 & 18 & 36 & 5 & 12.5 & 20 & 50 \\
\hline \multicolumn{9}{|c|}{ Education Qualification } \\
\hline $\begin{array}{l}\text { Graduation } \\
\text { Post }\end{array}$ & 41 & 68.3 & 26 & 52 & 12 & 30 & 15 & 37 \\
\hline $\begin{array}{l}\text { Graduation } \\
\text { Professional }\end{array}$ & 11 & 18.3 & 17 & 34 & 21 & 52.5 & 16 & 40 \\
\hline Degree & 8 & 13.3 & 7 & 14 & 7 & 17.5 & 9 & 22 \\
\hline \multicolumn{9}{|c|}{ Work Experience } \\
\hline $2-5$ yrs & 56 & 93.3 & 29 & 58 & 2 & 5 & & \\
\hline $6-10$ yrs & 3 & 5 & 20 & 40 & 16 & 40 & & \\
\hline $11-15$ yrs & & & & & 16 & 40 & 16 & 40 \\
\hline $16-20$ yrs & 1 & 1.7 & 1 & 2 & 6 & 15 & 14 & 35 \\
\hline $20-25$ & & & & & & & 10 & 25 \\
\hline \multicolumn{9}{|c|}{ Marital status } \\
\hline Married & 4 & 6.6 & 26 & 56 & 34 & 85 & 36 & 90 \\
\hline Unmarried & 56 & 91.8 & 23 & 42 & 6 & 15 & 4 & 10 \\
\hline Others & & & 1 & 2 & & & & \\
\hline
\end{tabular}

\section{Results and Discussion}

HI investigated whether work values varied with different career stages as stated by Super (1987) mainly Trial Stage, Establishment Stage, Maintenance Stage and Decline Stage. The work values were categorised as cognitive values, affective values, and instrumental values. ANOVA test revealed that there were significant differences in cognitive values at $\mathrm{p}<.05$ level across career stages $(F=(3,186) 4.484, p=.005)$. Post hoc test indicated that cognitive values were significantly higher in the decline stage as compared to the Trial stage and Establishment stage. ANOVA test revealed that there were significant differences in affective values at $p<.05$ level across career stages $(F=(3,186), 3.229 p=.024)$. Thus there are significant differences between the groups as a whole. Post hoc test indicated that affective values were valued significantly at the decline stages as compared to the Trial stage. Also, in the case of 
instrumental values, there were differences among career stages $(\mathrm{F}=(3,186) 2.190, \mathrm{p}=.036)$. Tukey results indicated that those instrumental values were found to be significantly higher in the decline stage as compared to the trial stage. This can also be seen in the descriptive table where the mean in the decline stage was found to be the highest (Table 4).

To assess $\mathrm{H} 2$, the ANOVA value was found to be $\mathrm{F}=(3,186) 2.377)$ $=.071$ which indicates that thus there are no significant differences in organisational commitment across career stages.

In order to assess $\mathrm{H} 3$, the ANOVA values were found to be $\mathrm{F}=$ $(3,386) 2.116=.1$. Since the p-value $>.05$ the null hypothesis is accepted, and thus there are no significant differences in job satisfaction.

Table 4: Descriptives

\begin{tabular}{|c|c|c|c|c|c|c|c|c|c|c|}
\hline \multirow[b]{2}{*}{$\begin{array}{l}\text { Career } \\
\text { Stages }\end{array}$} & \multicolumn{2}{|c|}{$\begin{array}{c}\text { Cognitive } \\
\text { values }\end{array}$} & \multicolumn{2}{|c|}{$\begin{array}{l}\text { Affective } \\
\text { Values }\end{array}$} & \multicolumn{2}{|c|}{$\begin{array}{c}\text { Instrumental } \\
\text { Values }\end{array}$} & \multicolumn{2}{|c|}{$\begin{array}{c}\text { Organizational } \\
\text { Commitment }\end{array}$} & \multicolumn{2}{|c|}{$\begin{array}{c}\text { Job } \\
\text { Satisfaction }\end{array}$} \\
\hline & 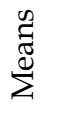 & कि & 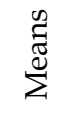 & कि & 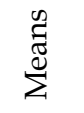 & कि & 舌 & कि & $\underset{\approx}{\approx}$ & कि \\
\hline $\begin{array}{l}\text { Trial } \\
\text { Stage }\end{array}$ & 3.8 & 0.9 & 3.8 & 0.82 & 3.8 & 0.82 & 4.49 & 0.783 & 4.82 & 1 \\
\hline $\begin{array}{l}\text { Establish } \\
\text { ment Stage }\end{array}$ & 3.8 & 1.05 & 3.8 & 1.09 & 3.8 & 1.09 & 4.71 & 0.88 & 4.87 & 0.95 \\
\hline $\begin{array}{l}\text { Mainte- } \\
\text { nance } \\
\text { Stage }\end{array}$ & 4.1 & 0.81 & 4.1 & 0.76 & 4.1 & 0.76 & 4.7 & 0.75 & 5.25 & 0.88 \\
\hline $\begin{array}{l}\text { Decline } \\
\text { Stage }\end{array}$ & $\begin{array}{r}4.3 \\
7\end{array}$ & 0.4 & 4.31 & 4.31 & 4.31 & 0.58 & 4.4 & 0.57 & 4.86 & 0.89 \\
\hline
\end{tabular}

There is no difference in work values, organisational commitment and job satisfaction across demographics (gender, marital status, level of education (Table 5). 
Table 5: ANOVA (Demographic variables)

\begin{tabular}{lrcr}
\hline & Gender & $\begin{array}{c}\text { Marital } \\
\text { Status }\end{array}$ & $\begin{array}{c}\text { Educational } \\
\text { Qualifications }\end{array}$ \\
\hline Cognitive Values & 0.783 & 0.146 & 0.365 \\
Affective Values & 0.889 & 0.168 & 0.209 \\
Instrumental Values & 0.29 & 0.449 & 0.209 \\
Organizational & & & \\
Commitment & 0.883 & 0.742 & 0.325 \\
Job Satisfaction & 0.903 & 0.091 & 0.655 \\
\hline
\end{tabular}

Current research has suggested that career stages can be defined by certain work values, however, this research often is contradictory in nature. This makes it difficult to form firm conclusions. Cennamo and Gardner (2008) and Smola and Sutton (2002) found no generational differences in intrinsic values. Lyon et al. (2005) and Real et al. (2010) did get generational differences. Cennamo and Gardner (2008) also found no difference in the importance of social values by generation while the other have found that Generational Y workers considered social values as important (Lyons et al., 2005; Real et al., 2010). The mean differences between work values between the four career stages studied were very small although sometimes statistically significant. Thus, values are similar across career stages, the ways in which individuals of each stage satisfy these values in the workplace may contribute to conflicts in the workplace. It has been seen that $72 \%$ of participants across generations placed high importance to family while the older generations this may be expressed by working long hours to earn a larger income whereas for younger workers it may mean working fewer hours to allow more time with family (Deal, 2007).

As has been the findings in this study, Smart (1998) also did not find that organisational commitment increase with career stage. This could be attributed to the fact that commitment could be to the profession rather than to the employing organisation.

Allen and Meyer (1993) noted that the career stage effect was only moderate, Therefore, rather than looking at a direct relationship between career stage and organisational variables (organisational commitment and job satisfaction), more recent investigations have looked at moderating variables between career stage and outcome 
variables. A study of remuneration strategies for different career stages found that employees differed in their job satisfaction and intention to remain based on their career stage (Flaherty and Pappas, 2003).

There is no difference in work values, organisational commitment and job satisfaction across demographics (gender, marital status, level of education).

\section{Conclusion}

By understanding the similarities and differences between career stages, human resources professionals and managers can enrich jobs which have an impact on commitment and satisfaction and finally productivity. Also while there is a need for understanding differences, there also lies the need to focus on our similarities which itself would lead to competitive advantage

\section{Implication}

\subsection{Implications for Research}

The cross-sectional design did not make it possible to determine whether differences between groups were linked to generational differences, life stages or career stages. Longitudinal research could separate the effects of age, generations etc.

\subsection{Practical Implications}

Employees in different career stages had differences in work values but they were fewer than expected. Mentoring and coaching could involve discussions about values and expectations which could increase the organisational commitment and job satisfaction across career stages. A clear and well-communicated values, mission and vision supplemented by good recruiting and assessment process could help deal with problems like turnover and recruitment costs for the company.

\section{References}

Allen, N.J, \& Meyer, J.P. (1999). Organizational commitment: Evidence of career stage effect. Journal of Business Research, 26, 49-61. 
Beyerlein, M. Johnson, D., \& Beyerlein. (1999). Advances in multidisciplinary studies of work teams Greenwich. Conn : JAI Press.

Bilz, J. (2008). Teacher career stages and job satisfaction. Unpublished dissertation, Walden University.

Cennamo, L., \& Gardner, D. (2008). Generational differences in work values, outcomes and person-organization values fit. Journal of Managerial Psychology, 23, 891-906.

Collins, J. 1988. Why we must keep Baby Boomers working. New Zealand Business, 12(8), 53.

Cron, W. L., \& Slocum, J. W. Jr. (1986). The influence of career stages on salespeople's job attitudes, work perceptions and performance. Journal of Marketing Research, 23, 119-129.

Deal, J.J (2007). Retiring the generation gap: how employees young and old can find common ground. San Francisco CA: Jossey Bass.

Drucker, P. (1992). Managing For the Future New York: Harper Collins.

Elizur, D. (1984). Facets of work values: A structural analysis of work outcomes. Journal of Applied Psychology, 69(3), 379-89.

Flaherty, K.E., \& Pappas, J.M. (2003). Using career stage theory to predict turnover intentions among sales people. Journal of Marketing Theory and Practice, 10, 48-57.

Hansen, J.C., \& Leuty, M .E. (2012). Work values across generations. Journal of Career Assessment, 20(1), 34-52.

Hui-Chun, Y., \& Miller, P. Leadership style: The X Generation and Baby Boomers compared in different cultural contexts. Leadership $\mathcal{E}$ Organization Development Journal, 26(1), 35-50.

Jurkiewicz, C.E. (2000). Generation X and the public employee. Public Personnel Management, 29, 55-74.

Karp, H., Fuller, C., \& Sirias, D. (2001). Bridging the Boomer gap: creating authentic teams for high performance at work. Black Publishing, Palo Alto, CA.

Lancaster, L.C., \& Stillman, D. (2002). When generations collide: Traditionalists, Baby Boomers, Generation Xers, Millennials: who they are, why they clash, how to solve the generational puzzle at work. New York: Harper Collins.

Levinson, D.J. (1986). A conception of adult development. American Psychologist, 41, 3-13.

Levinson, D. J., Darrow, C. N., Klein, E. B., Levinson, M. H., \& McKee, B. (1978). The seasons of a man's life. New York:

Loughlin, C., \& Barling, J. (2001). Young workers' values, attitudes, and behaviours. Journal of Occupational and Organizational Psychology, 74(4), 543-58.

Lyons, S. (2004). An exploration of generational values in life and at work. Dissertation Abstracts International, 3462A (UMI No. AATNQ94206). 
Lyons, S. Duxbury, L., \& Higgins, C. (2005). An empirical assessment of generational differences in work related values. Human Resource Management, 26, 62-71.

McArdle, S., Waters, L., Briscoe, J., \& Hall, D. (2007). Employability during unemployment: Adaptability, career identity and human and social identity. Journal of Vocational Behavior, 7, 247-26.

Mowday, R.T., Steers, R.M., \& Porter, L.W. (1979). The measurement of organizational commitment. Journal of Vocational Behavior, 14(2), 22447.

NASSCOM. (2011). NASSCOM HR Survey Report.

Ornstein, S., Cron. W. L., \& Slocum, J. W. Jr. (1989). Life stage vrs. career stage : a comparative test of theories of Levinson and Super. Journal of Organizational Behavior, 10, 117-133.

Parker, B., \& Cusmir, L.H. (1999). A generational and sex based view of managerial work values. Psychological Reports, 66, 947-951.

Putti, J. M., Aryee , S., \& Liang, T. K. (1989). Work values and organizational commitment: A study in the Asian context. Human Relations, 42, 275-88.

Real, K., Mitnick, A.D., \& Maloney, W. F. (2010). More similar than different: Millennials in the US building trades. Journal of Business Psychology, 25, 303-313.

Rhodes, S. (1983). Age-related differences in work attitudes and behaviour: a review and conceptual analysis. Psychological Bulletin 93, 328-367.

Riordan, C.M., Griffith, R.W., \& Weatherly, E.W. (2003). Age and workrelated outcomes: the moderating effects of status characteristics. Journal of Applied Social Psychology, 33(1), 37-57.

Rokeach, M. (1973). The nature of human values. New York: Free Press.

Slocum, J., \& Cron, W. (1985). Job attitudes and performance during three career stages. Journal of Vocational Behavior, 26, 126-145.

Smola, K.W., \& Sutton, C.D. (2002). Generational differences: Revisiting generational work values for the new millennium. Journal of Organisational Behaviour, 23, 363-82.

Super, D. E. (1957). The Psychology of careers. New York: Harper.

Super, D. E. (1984). Career and life development. In D. Brown \& L. Brooks (Eds), Career choice and development. Jossey-Bass, San Francisco.

Super, D. E., Selkowits, R. S. \& Thompson, A. S. (1981). Career development inventory: Adult Form I, Teachers' College. Columbia University, New York.

Twenge, J. M., Campbell, S.M., Hoffman, B.J. \& Lance, C.E. (2010). Generational differences in work values: Leisure and extrinsic values increasing, social and intrinsic values decreasing. Journal of Management, 36(5), 1117-1142. 
Arti Arun Kumar Work Values, Organizational Commitment and Job Satisfaction

Twenge, J. M. (2007). Generation me: why today's young Americans are more confident, assertive, entitled - and more miserable than ever before. Free Press.

Wiant, C.J. (1999). Are you listening to your employees? Journal of Environmental Health, 62, 51-52.

Warr, P.B., Cook, J.D., \& Wall,T.D. (1979). Scales for the measurement of work attitudes and aspects of psychological wellbeing. Journal of Occupational Psychology, 58(2), 129-48.

Semke, R., Raines, C., \& Filipcsak, B. 2000. Generations at work: managing the clash of veterans, boomers, xers and nesters in your workplace. New York: AMACOM. 